\title{
PERHITUNGAN DANA PENSIUN DENGAN METODE PROJECTED UNIT CREDIT DAN INDIVIDUAL LEVEL PREMIUM
}

\author{
YULIA ARFA \\ Program Studi Matematika, \\ Fakultas Matematika dan Ilmu Pengetahuan Alam, Universitas Andalas, \\ Kampus UNAND Limau Manis Padang, Indonesia, \\ email : yuliaarfa80@gmail.com
}

\begin{abstract}
Abstrak. Banyak perusahaan yang mengikuti program dana pensiun yang mana membutuhkan perhitungan aktuaria untuk memperkirakan jumlah dana yang akan dikeluarkan oleh perusahaan untuk dana pensiun. Metode aktuaria yang digunakan pada penelitian kali ini yaitu metode Projected Unit Credit dan metode Individual Level Premium. Dari sudut pandang pegawai yang mengikuti program dana pensiun, perhitungan digunakan dengan menggunakan asumsi gaji terakhir. Dari pembahasan, diperoleh untuk besar nilai manfaat yang sama, perhitungan dana pensiun dengan menggunakan metode Individual Level Premium lebih menguntungkan daripada perhitungan dengan menggunakan metode Projected Unit Credit.

Kata Kunci: Manfaat Pensiun, Iuran Normal, Projected Unit Credit, Individual Level Premium
\end{abstract}

\section{PENDAHULUAN}

Masa pensiun merupakan masa dimana seorang pegawai sudah tidak aktif lagi dipekerjaannya. Setiap pegawai akan mencapai usia pensiun dimana pegawai tidak bisa berkontribusi lagi di perusahaan tempat ia bekerja. Disaat pegawai mencapai usia pensiun, akan terjadi kekhawatiran dimana pegawai tidak bisa mempunyai penghasilan yang tetap untuk menjamin kehidupan masa tuanya.

Banyaknya pegawai yang pensiun pada suatu perusahaan setiap tahunnya tidak dapat diprediksi, sehingga perusahaan perlu untuk melakukan perhitungan anuitas pada pegawai, agar tidak terjadi ketidakstabilan keuangan dan kerugian pada perusahaan. Berdasarkan hal tersebut, dapat dilakukan perhitungan khusus untuk menghitung iuran normal yang akan dikeluarkan oleh para pegawai serta besar manfaat yang akan dikeluarkan oleh perusahaan saat pegawai mencapai usia pensiun. Besar iuran normal yang akan dibayarkan oleh para pegawai dapat dihitung dengan menggunakan metode perhitungan aktuaria.

Metode yang dapat digunakan pada perhitungan aktuaria adalah metode Projected Unit Credit dan metode Individual Level Premium. Metode Projected Unit Credit dan metode Individual Level Premium merupakan metode perhitungan aktuaria yang dapat digunakan untuk menghitung besar nilai iuran normal yang akan dibayarkan oleh para pegawai. Metode Projected Unit Credit merupakan metode 
perhitungan aktuaria yang membagi besar total manfaat dana pensiun yang kemudian dialokasikan dengan lama masa bekerja sedangkan metode Individual Level Premium merupakan metode perhitungan aktuaria dengan mengalokasikan nilai total manfaat dana pensiun secara merata sejak tanggal perhitungan aktuaria. Perhitungan akan dilakukan dengan menggunakan asumsi gaji terakhir.

Penulis tertarik untuk menghitung besar iuran normal yang akan dibayarkan tiap tahun oleh peserta program dana pensiun dan nilai manfaat yang akan diterima oleh pegawai saat mencapai usia pensiun dengan menggunakan asumsi gaji terakhir dengan metode Projected Unit Credit dan metode Individual Level Premium.

\section{LANDASAN TEORI}

\subsection{Asuransi}

Asuransi berasal dari kata insurance yang artinya pertanggungan. Asuransi merupakan suatu perjanjian antara pegawai perusahaan yang mengikuti program dana pensiun selaku nasabah dan perusahaan asuransi yang mengadakan program asuransi. Pihak asuransi merupakan pihak yang bersedia menanggung resiko terhadap sejumlah kerugian yang dapat terjadi di masa yang akan datang yang mungkin timbul setelah peserta program pensiun menyepakati persyaratan pembayaran premi. Premi merupakan sejumlah uang yang harus dibayarkan oleh pegawai yang menjadi peserta program dana pensiun yang akhirnya dapat diakumulasikan menjadi sejumlah dana yang akhirnya dapat menjadi penghasilan di masa tua pegawai tersebut.

Ada beberapa jenis asuransi yang telah dibuat oleh perusahaan asuranssi, seperti asuransi kendaraan bermotor untuk mengantisipasi jika terjadi kecelakaan ataupun kehilangan terhadap kendaraan yang didaftarkan, asuransi kesehatan untuk mengantisipasi adanya pengeluaran tidak terduga jika peserta program pensiun menderita penyakit dan harus membiayai pengobatan, asuransi pendidikan untuk memberikan perlindungan untuk pendidikan anak di masa datang, asuransi jiwa yang bertujuan untuk menanggung kerugian finansial tak terduga yang disebabkan karena meninggalnya terlalu cepat atau hidup seseorang terlalu lama, serta asuransi pensiun yang dapat menjadi penghasilan masa tua seseorang setelah tidak aktif lagi dalam pekerjaannya.

\subsection{Simbol Komutasi dan Tabel Mortalitas}

Tabel mortalitas merupakan tabel yang berisi peluang orang dapat bertahan hidup/mati pada umur tertentu. Tabel mortalitas juga dapat digunakan dalam perhitungan dana pensiun.

(1) $l_{x}$ pada tabel mortalitas merupakan banyaknya orang berusia $x$ yang masih bertahan hidup. Pada perhitungan dana penisun, $l_{x}$ pada tabel mortalitas dapat diartikan banyaknya pegawai yang mengikuti program dana pensiun yang masih aktif bekerja pada usia $x$.

(2) $p_{x}$ pada tabel mortalitas merupakan peluang hidup seorang berusia $x$ hingga 1 tahun ke depan. Pada perhitungan dana pensiun, $p_{x}$ dapat diartikan peluang pegawai berusia $x$ yang mengikuti program dana penisun dan masih aktif 
bekerja hingga 1 tahun ke depan.

(3) $q_{x}$ pada tabel mortalitas merupakan peluang seseorang berusia $x$ yang tidak dapat bertahan hidup hingga 1 tahun ke depan. Pada perhitungan dana pensiun, $q_{x}$ dapat diartikan peluang seseorang pegawai berusia $x$ yang mengikuti program dana pensiun dan tidak aktif lagi bekerja hingga 1 tahun ke depan.

Berikut merupakan beberapa simbol komutasi yang akan ditemukan selama perhitungan aktuaria untuk menghitung nilai manfaat serta besar iuran normal dari seorang pegawai yang menjadi peserta program dana pensiun.

$$
\begin{aligned}
d_{x} & =l_{x}+l_{x+1} \\
p_{x} & =\frac{l_{x+1}}{l_{x}} \\
q_{x} & =\frac{l_{x}-l_{x+1}}{l_{x}}=\frac{d_{x}}{l_{x}} \\
{ }_{n} q_{x} & =\frac{l_{x+n}}{l_{x}} \\
v & =\frac{1}{(1+i)} \\
D_{x} & =v^{x} l_{x} \\
N_{x} & =\sum_{i=0}^{w-x} D_{x+i}=D_{x}+D_{x+1}+\cdots+D_{\omega} \\
C_{x} & =v^{x+1} d_{x} \\
M_{x} & =\sum_{i=0}^{w-x} C_{x+i}=C_{x}+C_{x+1}+\cdots+C_{\omega}
\end{aligned}
$$

\subsection{Anuitas}

Anuitas terdiri atas dua jenis, yaitu:

(1) Anuitas Pasti (Certain Annuity).

Anuitas Pasti adalah serangkaian pembayaran atau penerimaan berkala yang dilakukan selama jangka waktu tertentu. Pembayaran dilakukan tanpa syarat.

(2) Anuitas Hidup (Life Annuity).

Anuitas Hidup adalah anuitas yang pembayarannya hanya dilakukan jika orang yang bersangkutan masih hidup. Deretan pembayaran ini dapat dilakukan secara berjangka, yaitu terbatas pada jangka waktu yang diberikan atau dibayarkan seumur hidup.

(3) Anuitas Seumur Hidup.

(i) Nilai tunai anuitas awal seumur hidup

$$
\ddot{a}_{x}=\frac{N_{x}}{D_{x}}
$$

(ii) Nilai tunai anuitas akhir seumur hidup

$$
a_{x}=\frac{N_{x+1}}{D_{x}}
$$




\subsection{Fungsi Dasar Aktuaria}

Fungsi dasar aktuaria merupakan fungsi-fungsi yang dapat digunakan dalam perhitungan aktuaria dalam menentukan besar nilai manfaat dan iuran normal yang akan dibayarkan oleh peserta program dana pensiun. Fungsi-fungsi yang dapat digunakan adalah sebagai berikut :

(1) Fungsi Kelangsungan Hidup

$$
{ }_{t} p_{x}=\frac{l_{x+t}}{l_{x}} .
$$

(2) Fungsi Tingkat Suku Bunga

$$
v^{n}=\frac{1}{(1+i)^{n}}
$$

(3) Fungsi Gaji

$$
S_{x+t}=S_{x}(1+c)^{t}
$$

(4) Fungsi Manfaat.

(i) Fungsi Manfaat Bedasarkan Asumsi Gaji Terakhir.

$$
S_{r-1}=S_{x}(1+c)^{r-1} \text {. }
$$

Sehingga diperoleh, besar nilai manfaat:

$$
B_{r}=k(r-e) S_{r-1}
$$

(ii) Fungsi Manfaat Berdasarkan Asumsi Rata-rata Gaji selama $n$ Tahun Terakhir.

$$
B_{r}=k(r-e) \frac{1}{n}\left[\sum_{t=r}^{r-1} S_{x}(1+c)^{t}\right]
$$

(iii) Fungsi Manfaat Berdasarkan Asumsi Rata-rata Gaji selama Bekerja.

Rata-rata gaji yang diharapkan selama bekerja yang dinotasikan dengan $\bar{S}$, dapat dirumuskan dengan :

$$
\bar{S}=\frac{1}{r-e}\left[S_{e}+\cdot+S_{x}+S_{x+1}+\cdot+S_{r-1}\right]
$$

Dari persamaan (2.15) dapat diperoleh besar nilai manfaat berdasarkan asumsi rata-rata gaji selama bekerja, dapat dirumuskan sebagai berikut:

$$
\begin{aligned}
& B_{r}=k(r-e) \frac{1}{r-e}\left[S_{e}+\cdot+S_{x}+S_{x+1}+\cdot+S_{r-1}\right] \\
& B_{r}=k\left[S_{e}+\cdot+S_{x}+S_{x+1}+\cdot+S_{r-1}\right]
\end{aligned}
$$




\subsection{Program Dana Pensiun}

Program dana pensiun merupakan bentuk balas jasa dari perusahaan terhadap pegawai karena pegawai telah mengabdikan waktu dan tenaganya untuk perusahaan tersebut. Program ini juga berfungsi sebagai tanggung jawab dari pihak perusahaan untuk memberikan jaminan kesejateraan hari tua untuk pegawai yang mengikuti program dana pensiun. Untuk itu, sejak adanya program dana pensiun, setiap pegawai negeri sipil dianjurkan untuk mengikuti program dana pensiun, sehingga para pegawai tidak perlu mengkhawatirkan penghasilan hari tuanya setelah mencapai usia pensiun dan tidak bisa aktif lagi dalam bekerja.

Dalam sistem dana pensiun, ada beberapa manfaat yang akan diberikan sebagai manfaat tambahan bila terjadi kematian, pensiun dipercepat, pensiun yang diakibatkan karena tidak bisa lagi bekerja (cacat), atau pensiun pada saat telah mencapai usia pensiun yang telah ditentukan [3], yaitu :

(1) Manfaat pensiun janda/duda yang dibayarkan karena meninggal.

(2) Manfaat pensiun yang dipercepat, akibat tertanggung keluar dari tempat dia bekerja.

(3) Manfaat pensiun yang dipercepat, yang diakibatkan karena tertanggung tidak dapat bekerja lagi karena cacat.

(4) Manfaat pensiun pada tertanggung pada saat mencapai usia pensiun yang telah ditentukan.

\subsection{Metode Perhitungan Aktuaria}

Metode perhitungan aktuaria untuk program dana pensiun dapat dibagi menjadi dua garis besar, yaitu metode accured benefit cost dan metode projected benefit cost. Metode accured benefit cost merupakan metode perhitungan aktuaria yang menunjukkan nilai manfaat pensiun berdasarkan jasa yang telah diberikan karyawan pada masa kerja, sedangkan metode projected benefit cost merupakan metode perhitungan aktuaria yang menunjukkan nilai manfaat pensiun berdasarkan jasa yang telah diberikan ataupun yang akan diberikan oleh karyawan selama masa kerja. Salah satu bagian dari metode accured benefit cost adalah metode Projected Unit Credit, sedangkan salah satu bagian dari metode projected benefit cost adalah metode Individual Level Premium.

\section{Metode Penelitian}

Untuk menyelesaikan masalah diatas dapat dilakukan dengan langkah-langkah sebagai berikut:

(a) Menghitung nilai tunai anuitas awal seumur hidup dan nilai tunai anuitas awal berjangka pada peserta program pensiun.

(b) Menghitung nilai manfaat pensiun dari peserta program pensiun.

(c) Menghitung nilai sekarang dari manfaat pensiun pada peserta program pensiun.

(d) Menghitung iuran normal dari peserta program pensiun dengan menggunakan metode Projected Unit Credit. 
(e) Menghitung iuran normal dari peserta program pensiun dengan menggunakan metode Individual Level Premium.

\section{Projected Unit Credit dan Individual Level Premium pada Perhitungan Dana Pensiun}

Nilai sekarang dari manfaat pensiun adalah sebagai berikut.

$$
\begin{aligned}
{ }^{r}(P V F B)_{x} & =B_{r} \ddot{a}_{r} v^{r-x}{ }_{r-x} p_{x}, \\
& =B_{r} \ddot{a}_{r} \frac{v^{r}}{v^{x}} \frac{l_{r}}{l_{x}}, \text { dari persamaan }(2.2), \\
& =B_{r} \ddot{a}_{r} \frac{D_{r}}{D_{x}}, \text { dari persamaan (2.6). }
\end{aligned}
$$

Nilai iuran normal dengan metode Projected Unit Credit dihitung sebagai berikut.

$$
\begin{aligned}
r(N C)_{x} & =\frac{1}{r-e}{ }^{r}(P V F B)_{x}, \\
& =\frac{1}{r-e} B_{r} \ddot{a}_{r} v^{r-x}{ }_{r-x} p_{x}, \\
& =\frac{1}{r-e} B_{r} \ddot{a}_{r} \frac{v^{r}}{v^{x}} \frac{l_{r}}{l_{x}} \text {, dari persamaan (2.2), } \\
& =\frac{1}{r-e} B_{r} \ddot{a}_{r} \frac{D_{r}}{D_{x}}, \text { dari persamaan (2.6). }
\end{aligned}
$$

Skema pembayaran iuran normal selama masa kerja pada peserta yang mulai mengikuti program pensiun dari usia $e$ tahun sampai berusia $r-1$ tahun dapat dirumuskan sebagai berikut.

$$
1+v p_{e}+v^{2} p_{e}+\cdots+v_{r-1-e}^{r-1-e} p_{e}=\ddot{a}_{e: \bar{r}-e} .
$$

Sehingga perhitungan iuran normal dengan menggunakan metode Individual Level Premium dapat dirumuskan dengan:

$$
\begin{aligned}
{ }^{r}(N C)_{e}\left(\ddot{a}_{e: \bar{r}-e}\right) & ={ }^{r}(P V F B)_{e}, \\
& =B_{r} a_{r} v^{r-\ddot{e}}{ }_{r-e} p_{e}, \\
& =B_{r} \ddot{a}_{r}\left(\frac{D_{r}}{N_{e}-N_{r}}\right) .
\end{aligned}
$$

\section{Aplikasi Kasus}

Perhitungan iuran normal pada asuransi dana pensiun dengan menggunakan metode Projected Unit Credit dan metode Individual Level Premium akan diterapkan dalam contoh kasus berikut.

Seorang pegawai berjenis kelamin laki-laki diangkat menjadi pegawai pada usia 25 tahun $(e=25)$, pegawai tersebut mulai mengikuti program asuransi dana pensiun terhitung saat diangkat menjadi pegawai dan mulai terhitung pensiun pada usia 56 tahun $(r=56)$. Gaji pokok yang diterima pada tahun pertama adalah sebesar $R p \cdot 2.100 .000,00$ dan diasumsikan meningkat $2 \%(c=2 \%)$ pertahun dari gaji 
pokok tahun pertama yang didapatkan dan besar nilai proporsi gaji yang diberikan untuk dana pensiun sebesar $2 \%(k=2 \%)$. Perhitungan dilakukan pada saat peserta terdaftar program dana asuransi dana pensiun $(x=25)$. Perhitungan dana pensiun untuk peserta berusia $x=25$ tahun adalah:

(1) Perhitungan anuitas hidup.

$$
\begin{aligned}
\ddot{a}_{r} & =\frac{N_{56}}{D_{56}}, \\
& =\frac{3885,432753}{432,8170107} \\
& =8,97707959 .
\end{aligned}
$$

(2) Perhitungan besar manfaat pensiun.

$$
\begin{aligned}
B_{r} & =k\left((r-e) S_{r-1}\right), \\
B_{56} & =2 \%((56-25) 45.646 .312, \\
& =28.300 .713,44 .
\end{aligned}
$$

Sehingga besar manfaat yang diterima oleh peserta program dana pensiun pada kasus ini adalah 28.300.713, 44 .

(3) Perhitungan nilai sekarang dari manfaat pensiun

$$
\begin{aligned}
r(P V F B)_{x} & =B_{r} \ddot{a}_{r} \frac{D_{r}}{D_{x}}, \\
{ }^{56}(P V F B)_{25} & =B_{56} \ddot{a}_{56} \frac{D_{56}}{D_{25}}, \\
& =(28.300 .713,44)(8,97707959) \frac{432,8170107}{9061,373666}, \\
& =12.135 .087,71 .
\end{aligned}
$$

Sehingga diperoleh nilai sekarang dari manfaat pensiun yang akan diterima oleh peserta program dana pensiun setelah mencapai usia pensiun setiap tahunnya adalah 12.135.087, 71 .

(4) Perhitungan iuran normal dengan metode aktuaria.

(a) Iuran Normal dengan Metode Projected Unit Credit.

Iuran normal yang akan dibayarkan oleh peserta program dana pensiun yang berusia $x=25$ tahun dengan usia pensiun adalah $r=56$ tahun, adalah:

$$
\begin{aligned}
{ }^{r}(N C)_{x} & =\left(\frac{1}{r-e}\right) B_{r} \ddot{a}_{r} \frac{D_{r}}{D_{x}}, \\
{ }^{56}(N C)_{25} & =\left(\frac{1}{56-25}\right)(28.300 .713,44)(8,97707959) \frac{432,8170107}{9061,373666}, \\
& =391.454,28 .
\end{aligned}
$$

Jadi, besarnya iuran normal yang akan dibayarkan oleh peserta program dana pensiun yang berusia $x=25$ tahun dengan usia pensiun adalah $r=56$ tahun dengan menggunakan metode Projected Unit Credit adalah sebesar Rp. 391.454, 28. 
(b) Iuran Normal dengan Metode Individual Level Premium.

Iuran normal yang akan dibayarkan oleh peserta program dana pensiun yang mulai mengikuti program dana pensiun pada usia $e=25$ tahun dengan usia pensiun $r=56$ tahun, dan mulai melakukan perhitungan pada saat peserta terdaftar program dana pensiun $x=25$ tahun.

$$
\begin{aligned}
r(N C)_{e}\left(\frac{N_{e}-N_{r}}{D_{e}}\right) & =B_{r} \ddot{a}_{r} \frac{D_{r}}{D_{e}} \\
{ }^{56}(N C)_{25}\left(\frac{N_{25}-N_{56}}{D_{25}}\right) & =B_{56} \ddot{a}_{56} \frac{D_{56}}{D_{25}}, \\
{ }^{56}(N C)_{25}\left(\frac{97511,19301-3885,432753}{9061,373666}\right) & =(28.300 .713,44)(8,97707959) \frac{432,8170107}{9061,373666}, \\
{ }^{56}(N C)_{25}(10,33240254) & =12.135 .082,71, \\
{ }^{56}(N C)_{25} & =1.174 .468,63 .
\end{aligned}
$$

Jadi, besarnya iuran normal yang akan dibayarkan oleh peserta program dana pensiun berusia $x=25$ tahun dengan usia pensiun $r=56$ tahun adalah sebesar $R p .1 .174 .468,63$.

Berikut merupakan tabel perhitungan iuran normal yang akan dibayarkan oleh peserta program dana pensiun dengan menggunakan metode Projected Unit Credit dan metode Individual Level Premium setiap tahunnya :

\begin{tabular}{|c|c|c|}
\hline $\mathrm{Usia}(x)$ & $\mathrm{PUC}(\mathrm{NC})[\mathrm{Rp}]$ & $\mathrm{ILP}(\mathrm{NC})[\mathrm{Rp}]$ \\
\hline 25 & 391.454 & 1.174 .468 \\
\hline 26 & 430.966 & 1.174 .468 \\
\hline 27 & 474.456 & 1.174 .468 \\
\hline 28 & 522.314 & 1.174 .468 \\
\hline 29 & 574.977 & 1.174 .468 \\
\hline 30 & 632.943 & 1.174 .468 \\
\hline
\end{tabular}

\begin{tabular}{|c|c|c|}
\hline Usia $(x)$ & PUC(NC) $[\mathrm{Rp}]$ & ILP(NC) $[\mathrm{Rp}]$ \\
\hline 41 & 1.826 .138 & 1.174 .468 \\
\hline 42 & 2.012 .274 & 1.174 .468 \\
\hline 43 & 2.217 .848 & 1.174 .468 \\
\hline 44 & 2.444 .988 & 1.174 .468 \\
\hline 45 & 2.696 .119 & 1.174 .468 \\
\hline 46 & 2.974 .028 & 1.174 .468 \\
\hline
\end{tabular}

\begin{tabular}{|c|c|c|}
\hline $\operatorname{Usia}(x)$ & PUC(NC) $[\mathrm{Rp}]$ & $\mathrm{ILP}(\mathrm{NC})[\mathrm{Rp}]$ \\
\hline 31 & 696.767 & 1.174 .468 \\
\hline 32 & 767.057 & 1.174 .468 \\
\hline 33 & 844.464 & 1.174 .468 \\
\hline 34 & 929.691 & 1.174 .468 \\
\hline 35 & 1.023 .541 & 1.174 .468 \\
\hline 36 & 1.126 .920 & 1.174 .468 \\
\hline 37 & 1.240 .841 & 1.174 .468 \\
\hline 38 & 1.366 .415 & 1.174 .468 \\
\hline 39 & 1.504 .862 & 1.174 .468 \\
\hline 40 & 1.657 .586 & 1.174 .468 \\
\hline
\end{tabular}

\begin{tabular}{|c|c|c|}
\hline Usia $(x)$ & PUC(NC) $[\mathrm{Rp}]$ & $\mathrm{ILP}(\mathrm{NC})[\mathrm{Rp}]$ \\
\hline 47 & 3.281 .868 & 1.174 .468 \\
\hline 48 & 3.623 .207 & 1.174 .468 \\
\hline 49 & 4.002 .096 & 1.174 .468 \\
\hline 50 & 4.423 .139 & 1.174 .468 \\
\hline 51 & 4.891 .770 & 1.174 .468 \\
\hline 52 & 5.414 .245 & 1.174 .468 \\
\hline 53 & 5.997 .593 & 1.174 .468 \\
\hline 54 & 6.649 .484 & 1.174 .468 \\
\hline 55 & 7.378 .776 & 1.174 .468 \\
\hline 56 & 8.195 .441 & 1.174 .468 \\
\hline
\end{tabular}


Dari tabel tersebut diperoleh bahwa pembiayaan iuran normal dengan metode Projected Unit Credit terus meningkat setiap tahunnya sedangkan pembiayaan iuran normal dengan metode Individual Level Premium cenderung tetap selama bekerja sampai memasuki usia pensiun, hal ini disebabkan karena perhitungan pembiayaan iuran normal dengan metode Individual Level Premium tidak dipengaruhi oleh usia peserta saat tahun perhitungan aktuaria (saat peserta berusia $x$ tahun), namun hanya dipengaruhi oleh usia peserta saat memasuki program pensiun (saat peserta berusia $e$ tahun).

\section{Penutup}

\subsection{Kesimpulan}

Hasil nilai iuran normal yang diperoleh dengan menggunakan metode Projected Unit Credit lebih besar dibandingkan dengan nilai iuran normal yang dihitung menggunakan metode Individual Level Premium. Sehingga, dari sudut pandang pegawai yang mengikuti program dana pensiun, akan lebih menguntungkan jika perhitungan dilakukan dengan menggunakan metode Individual Level Premium. Karena dengan besar nilai manfaat yang sama, pegawai bisa membayarkan iuran normal yang lebih kecil jika perhitungan dihitung dengan menggunakan metode Individual Level Premium dibandingkan dengan perhitungan dengan metode Projected Unit Credit.

\subsection{Saran}

Pada kasus ini, penulis menghitung besar nilai manfaat dan iuran normal untuk satu orang peserta program dana pensiun. Oleh sebab itu, penulis menyarankan unutuk penelitian selanjutnya agar dilakukan untuk penelitian perhitungan besar dana pensiun dengan menggunakan metode Projected Unit Credit dan metode Individual Level Premium untuk kasus asuransi dana pensiun gabungan.

\section{Daftar Pustaka}

[1] Aitken, W.H. 1994. Problem Solving Approach to Pension Funding and Valuation, $2^{\text {nd }}$ edition. Actex, Winsted

[2] Takashi, F. 1993. Matematika Asuransi Bagian I. Incorporated Foundation Oriental Life Insurance Cultural Development Center, Tokyo

[3] Takashi, F. 1993. Matematika Asuransi Bagian II. Incorporated Foundation Oriental Life Insurance Cultural Development Center, Tokyo

[4] Winklevoss, H.E. 1993. Pension Mathematics with Numerical Illustration, $2^{\text {nd }}$ edition. Pension Research Council, USA 